\title{
Characterized Organic Pollutants and Their Health Effects in Sampled Groundwater Around Ilorin Metropolis
}

\author{
Oluwaseun Emmanuel Odipe ${ }^{1, ~ *}$, Henry Olawale Sawyerr ${ }^{1}$, Solomon Olayinka Adewoye ${ }^{2}$ \\ ${ }^{1}$ Department of Environmental Health Sciences, School of Allied Health and Environmental Science, College of Pure and Applied Science, \\ Kwara State University, Malete, Nigeria \\ ${ }^{2}$ Department of Pure and Applied Biology, Faculty of Pure and Applied Science, Ladoke Akintola University of Technology, Ogbomosho, \\ Nigeria
}

Email address:

odipe@yahoo.com (O. E. Odipe), henry.sawyerr@kwasu.edu.ng (H. O. Sawyerr), soadewoye@lautech.edu.ng (S. O. Adewoye)

${ }^{*}$ Corresponding author

\section{To cite this article:}

Oluwaseun Emmanuel Odipe, Henry Olawale Sawyerr, Solomon Olayinka Adewoye. Characterized Organic Pollutants and Their Health Effects in Sampled Groundwater Around Ilorin Metropolis. International Journal of Environmental Protection and Policy.

Vol. 8, No. 2, 2020, pp. 36-43. doi: 10.11648/j.ijepp.20200802.11

Received: March 6, 2020; Accepted: March 23, 2020; Published: April 30, 2020

\begin{abstract}
The study was aimed at determining the possible volatile organic compounds present in groundwater from handdug wells within and around filling stations across Ilorin metropolis as well as to ascertain the possible sources of the contaminants and their health effects. Water samples were obtained from twenty-six (26) wells that were found within the scope of stations above the age of 15 years and functioning with underground storage tank capacities of over 33,000 L each for different petroleum products stored above the water level. Laboratory analysis to determine volatile organic compounds and their concentrations were carried out using the gas chromatography- mass spectrophotometer (GC-MS) after prior extraction of hydrocarbon from the water samples by the Liquid-Liquid Extraction (LLE) method. The result revealed a total of fifty-three (53) VOCs across samples where nonanal, dodecane, methyl palmitate, heptanophenone, 13, hexyloxacyclotridec - 10 - en - 2 - one, cyclohexane, octyl, decahydro- 4, 4, 8, 9, 10 - pentamethyl naphthalene, $(\mathrm{z})$ - 3 - heptene, were the most frequently occurring compounds, which could be traced to anthropogenic activities involving the use of paints, detergents, stain removers, leaking underground storage tanks, piped networks containing petroleum products as the possible sources of release into the environmental media. Related health impacts from exposure to these contaminants includes brain damage, cancer, tumours, anaemia, central and peripheral nervous system breakdown, liver, bones, autism, Skin, eye, and nose irritation, headache, dizziness, narcosis, and death at high levels of exposure. The study concluded that groundwater sources at close proximity to filling stations are susceptible to contamination through activities in the stations and such water resource should be treated before consumption and use to avoid negative health effects.
\end{abstract}

Keywords: Volatile Organic Compounds, Groundwater, Filling Stations, Ilorin Metropolis, Health Impact

\section{Introduction}

Ilorin Metropolis, the urban centre of the ancient Ilorin emirate (the present day capital town) of Kwara State, NorthCentral, Nigeria lies within coordinates of Latitude $8^{\circ} 30^{\prime} \mathrm{N}$ and Longitude $4^{\circ} 30^{\prime} \mathrm{E}$ respectively and it covers an approximated area of $180 \mathrm{sqkm}$ within $765 \mathrm{sqkm}$ of the three (3) local government areas in Ilorin town [1]. Ilorin is a fast growing town that is geographically divided into three Local government areas namely Ilorin East, Ilorin South and Ilorin
West, with populations at 204,310, 208,691, 364,666 respectively as at the 2006 Nationwide census totally 777,667 [2], and geopolitically subdivided into 35 wards.

After the creation of Kwara State in 1967 and Ilorin made the state capital, with its North central geographical positioning in Nigeria aided various investors to come in and set up industries of different types and grades. The establishment of these industries led to relative increase in population and demand of fossil fuels and petroleum products for power generation, automobile and transport, household fuels amongst others which has indiscriminately 
promoted the siting of filling stations in all corners of the city.

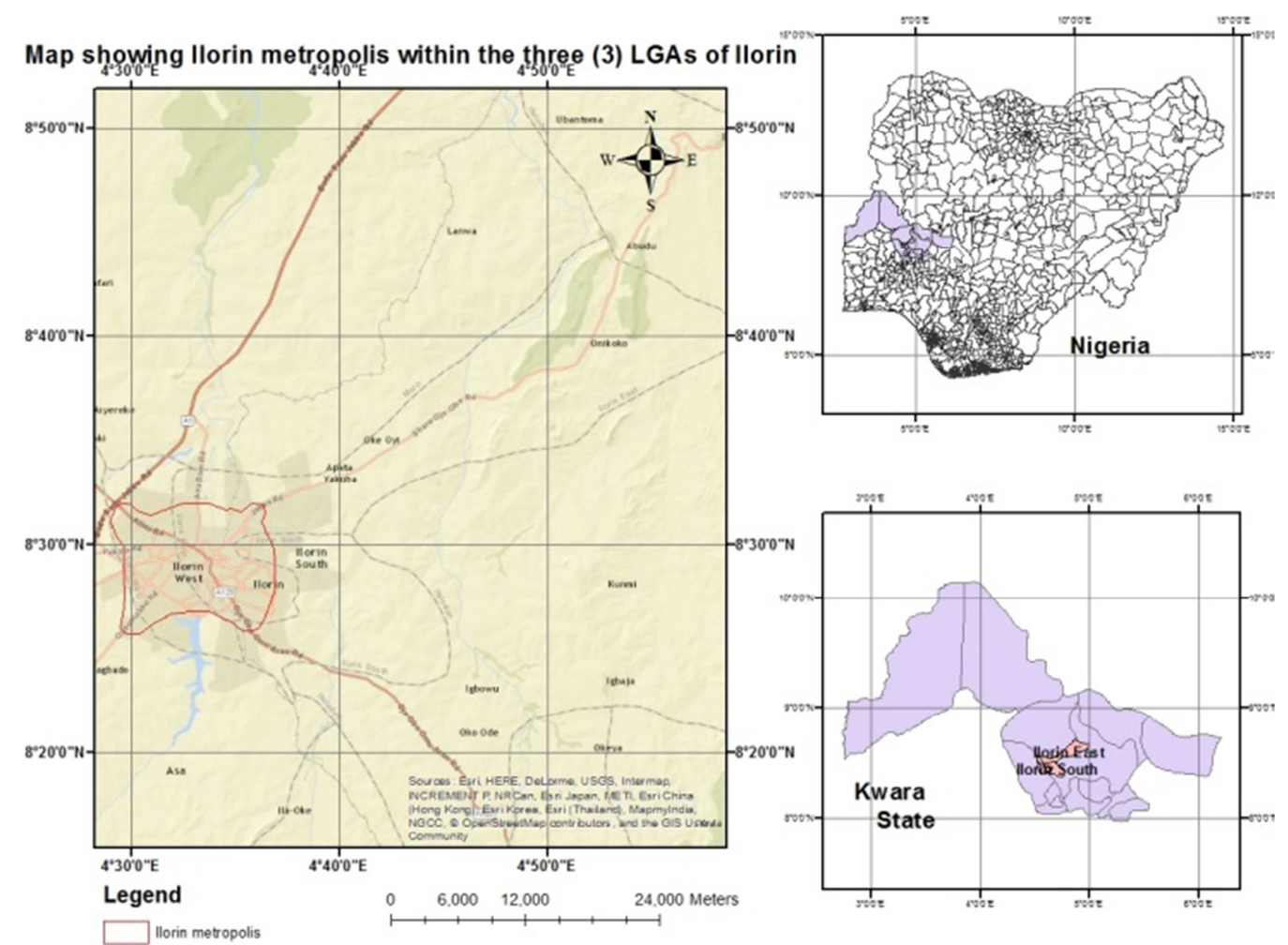

Figure 1. Showing the map of Ilorin metropolis within the three (3) local government areas of Ilorin town [1].

Many anthropogenic activities in our neighbourhood pollutes the environment where toxic and health threatening contaminants are released into soil, water and air. Activities in a filling station and possible leaking underground storage tanks can release numerous chemicals that also pollutes groundwater since the products available in these stations are complex blends of countless compounds majorly hydrocarbons. Examples of these contaminants are classified as volatile organic compounds (VOC), oxygenates, heavy metals, polycyclic aromatic hydrocarbon (PAH), phenols, chlorobenzenes, phthalates, and organochlorides etc. [3].

Hydrocarbons are organic compounds made up of carbon and hydrogen atoms only or with more elements like oxygen, sulphur, silicon, halogens etc., they are readily available substances around us for use such as in petroleum products, cosmetics, plastics, bleach, greases etc. [4].

The objective of this study therefore is to determine the concentration of volatile organic compounds present in groundwater obtained from within and around sampled filling stations in the metropolis and to evaluate the potential health risk from consumption and usage of these water resources.

\section{Materials and Methods}

\subsection{Geology, Hydrogeology and Drainage Pattern of the Study Area}

The occurrence of groundwater is greatly influenced by the local geological conditions which ultimately control yields.
Groundwater resources are often, but not always renewable. Groundwater occurrence depends primarily on geology, geomorphology/weathering and rainfall (both current and historic). This interplay of these three factors gives rise to complex hydrogeological environments with countless variations in the quantity, quality, ease of access and renewability of groundwater resources [5].

The Ilorin Metropolis is underlain by the migmatite gneiss rock type of the Precambrian Basement Complex Rocks of Nigeria as shown in Figure 2 [6]. In basement complex area, groundwater is contained within the weathered and or fractured/jointed basement columns [7]. The availability of groundwater in areas underlain by crystalline basement rocks depends on the development of thick soil overburden (overburden aquifers), the presence of weathered layers or fractures that are capable of holding water (fractured crystalline aquifers). The storage of groundwater is confined to fractures and fissures in the weathered zone of crystalline rocks, the thickness of which range from $<10-60 \mathrm{~m}$ in arid and humid environment. The groundwater resources here are usually limited.

The unconfined nature and the near-surface occurrence of the aquifer system makes it vulnerable to surface/near surface pollutants such as seepages from underground storage tanks of petroleum products.

Ilorin metropolis is mainly drained by River Asa, with many tributaries leading to a dendritic drainage pattern as shown in Figure 3 [8-10]. River Asa drains in a North-South direction before being dammed as Asa dam, its flow pattern divides the metropolis into eastern and western parts. Other 
rivers within the metropolis that drains into Asa river includes River Agba (also dammed), River Alalubosa, River Okun, River Osere, River Aluko, and River Odota.

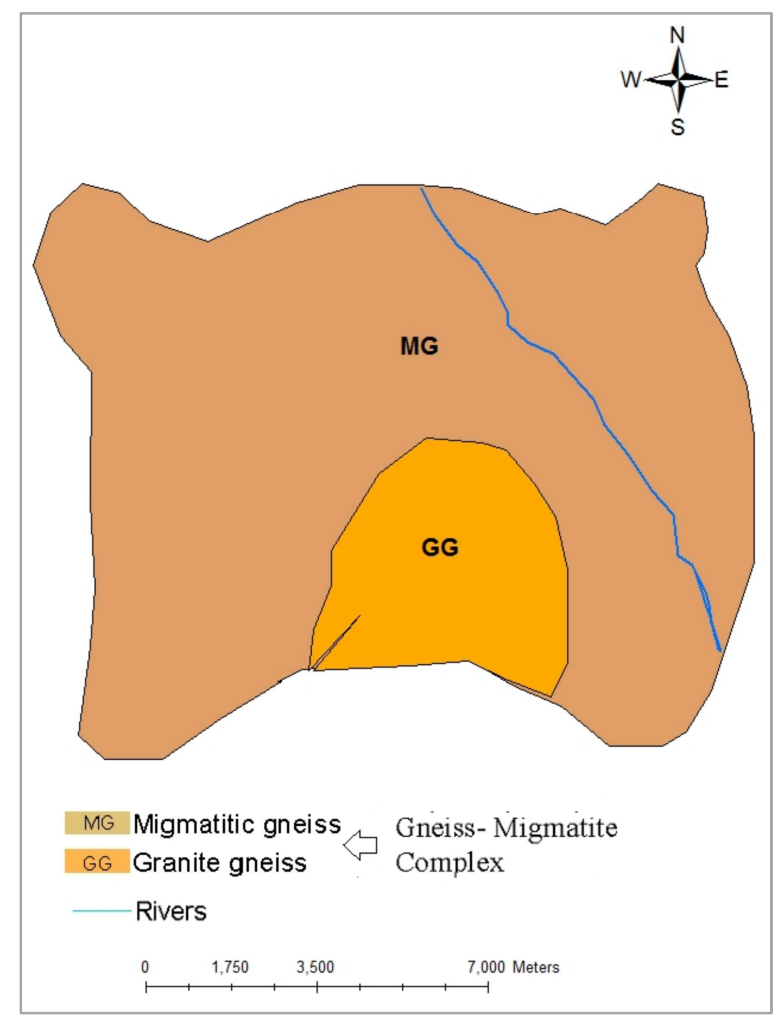

Figure 2. Geological map of Ilorin metropolis.

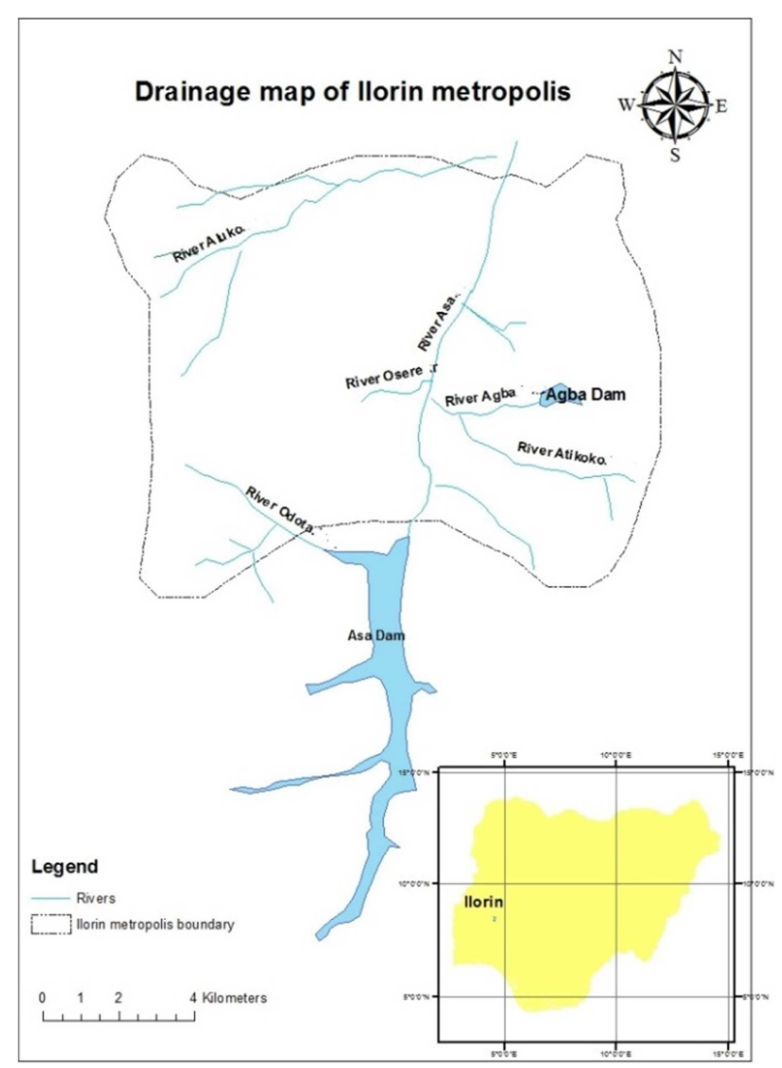

Figure 3. The drainage pattern of Ilorin metropolis and major rivers.

\subsection{Methods}

Laboratory analysis of groundwater samples collected from hand-dug wells within and around functioning filling stations of above 15 years of operation within the metropolis was collected to detect possible volatile organic compounds and their concentrations. Twenty-six (26) stations were sampled and a total of fifty-two (52) samples (including duplicates) were collected (Figure 4). Analyses carried out involved the extraction of hydrocarbon from the water samples and characterization using a gas chromatography from Agilent USA hypherated to a mass spectrophotometer (5975C) with triple axis detector equipped with an auto injector (10ul syringe) where Helium gas was used as a carrier gas.

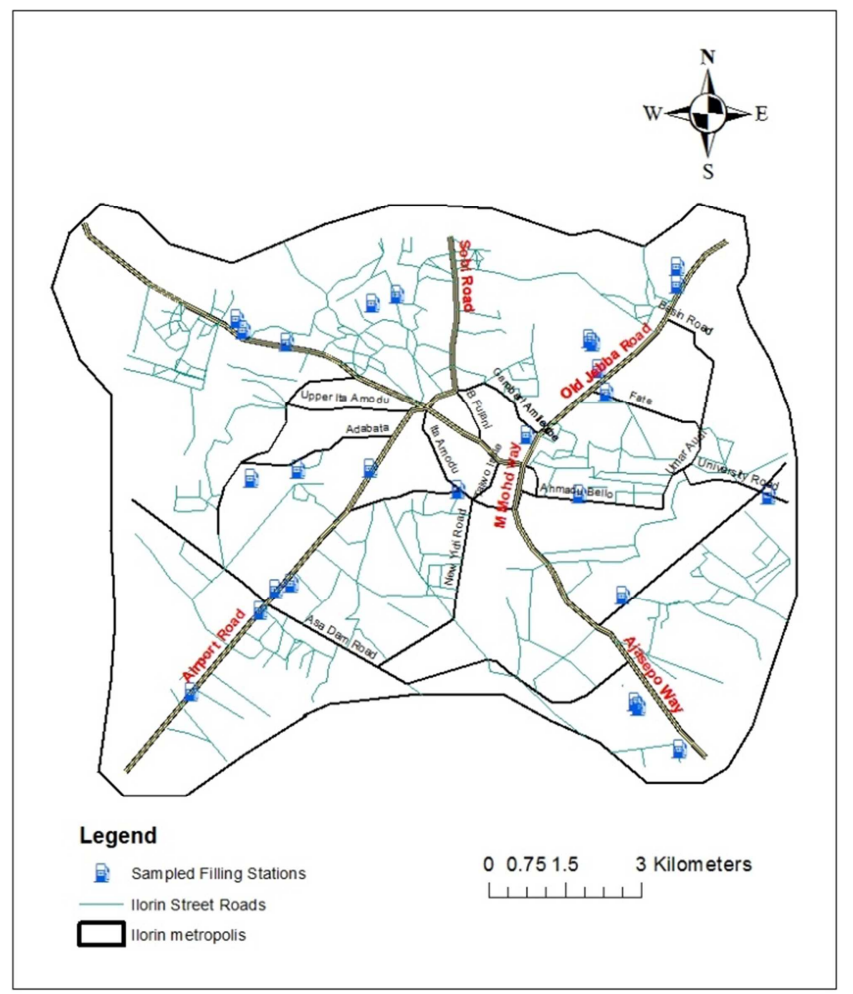

Figure 4. The Spatial Distribution of the Selected Sample Stations.

\subsubsection{Procedure for Extraction of Hydrocarbon from Water Samples}

For the extraction of hydrocarbon from the water sample, the Liquid-Liquid Extraction (LLE) method was used. The Liquid-Liquid extraction is a method used to separate compounds based on their relative solubilities in different immiscible liquids. In the LLE procedure, the sampled water was extracted by using organic solvents, the water sample was poured into a separatory funnel and the mixture of $100 \mathrm{ml}$ $\mathrm{n}$-hexane and Dichloromethane $(1: 1 \mathrm{v} / \mathrm{v})$ was added and well shaken for 2 minutes. The mixture in the separatory funnel was left to stand for 10minutes which allowed the separation of an aqueous phase from the organic phase. The aqueous phase was carefully drained away and then the organic phase was poured into a glass funnel containing $20 \mathrm{~g}$ of anhydrous sodium sulfate and re-extracted with $50 \mathrm{ml}$ of the solvent mixture. The organic extract (free from water) was 
transferred into $2 \mathrm{ml}$ vial carefully for the next phase of organic characterization using the Gas Chromatography/ Mass Spectroscopy. All samples (including duplicates) were treated in the same manner as indicated above.

\subsubsection{Procedure for Determining Petroleum Hydrocarbon Compounds Present and Their Concentrations}

All experiments were performed with a high resolution GC-MS by Agilent Technologies of 7890A GC system and 5975C inert MSD with Triple-Axis Detector using the EPA Method 8021 for Volatile Organic Compounds at the Department of Chemical Engineering, University of Ilorin, Nigeria; a gas carrier of Helium at speed of $9 \mathrm{~mL} / \mathrm{min}$ was measured at $35^{\circ} \mathrm{C}$; the oven temperature was programmed as follows:

1. $35^{\circ} \mathrm{C}$ for $12 \mathrm{mins}$,

2. $35^{\circ} \mathrm{C}-60^{\circ} \mathrm{C}$ at $5^{\circ} \mathrm{C} / \mathrm{min}$,

3. then $60^{\circ} \mathrm{C}$ for $1 \mathrm{~min}$,
4. $60-200^{\circ} \mathrm{C}$ at $17^{\circ} \mathrm{C} / \mathrm{min}$ and,

5. Final temperature at $200^{\circ} \mathrm{C}$ for $5 \mathrm{~min}$.

The analysis procedure started with a solvent blank followed by calibration verification standard, method blank and finally the extracts (oil extracts) analysis where $2 \mu \mathrm{L}$ of samples were introduced into the injector.

The Chromatographic peaks were processed using the Ms Solution software provided by the supplier to control the system and acquire the data. Identification of the compounds was carried out by comparing the mass spectra obtained with those of the standard mass spectra from NIST library (NISTII).

\section{Results}

The result for volatile organic compounds and their concentrations across all samples is shown in the Table 1.

Table 1. Occurrence frequency and area percent of VOCs identified across samples.

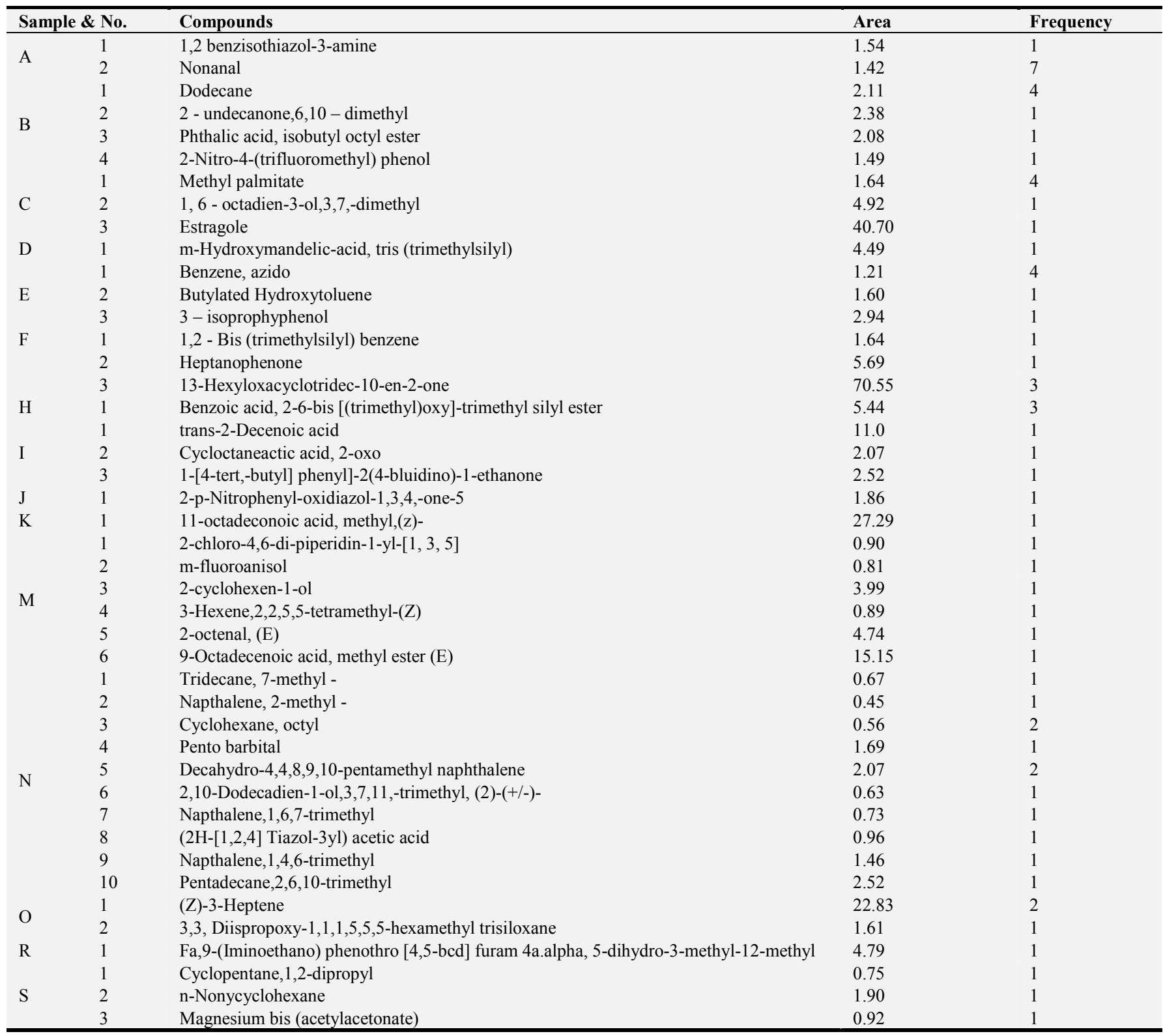




\begin{tabular}{|c|c|c|c|c|}
\hline & No. & Compounds & Area & Frequency \\
\hline \multirow{3}{*}{$\mathrm{T}$} & 4 & Cyclohexane decycl & 0.84 & 1 \\
\hline & 1 & Aziridine,1-hexyl & 2.01 & 1 \\
\hline & 2 & 1-phenizine carboxylic acid,6-1 (-1 hydroxy-ethyl) -methyl estr & 1.68 & 1 \\
\hline \multirow{2}{*}{ V } & 1 & Tetrasiloxane decamethyl & 0.85 & 1 \\
\hline & 2 & Heneicosane & 27.24 & 1 \\
\hline \multirow[t]{3}{*}{$\mathrm{W}$} & 1 & Cyclotetrasiloxane Octamethyl & 2.51 & 1 \\
\hline & 2 & Methoxyacetic acid, 4-tetradecyl ester & 0.92 & 1 \\
\hline & 3 & Diethyl 2,6-dimethyl-4-phenyl - 3,5-pyridine dicarboxylate & 1.20 & 1 \\
\hline \multirow{2}{*}{$\mathrm{X}$} & 1 & 1-Hexanone, 5-methyl-1-phenyl & 5.60 & 1 \\
\hline & 2 & Heptanophenone & 3.90 & 1 \\
\hline
\end{tabular}

\section{Discussion}

Of the 26 samples, a total 53 VOCs were found across all samples except in samples G, L, P, U, and V and Z. Nonanal; Dodecane; Methyl palmitate; Heptanophenone; 13, Hexyloxacyclotridec - 10 - en - 2 - one; Cyclohexane, octyl; Decahydro- 4, 4, 8, 9, 10 - pentamethyl naphthalene; $(\mathrm{z})-3$
- Heptene, were the most frequently occurring compounds with frequencies of above one (Table 1).

Across these samples, volatile organic compounds were found at different concentration ranging from $0.45 \%-70.55 \%$ area and possible contamination in this aquifers could be traced to conditions such as paints, detergents, stain removers, leaking underground storage tanks, piped networks containing petroleum products etc. (Table 2).

\subsection{Possible Sources of Identified Volatile Organic Compounds}

Table 2. Volatile organic compounds with their possible sources.

\begin{tabular}{|c|c|}
\hline Compounds & Possible Sources \\
\hline 1,2 benzisothiazol-3-amine & $\begin{array}{l}\text { emulsion paints, adhesives, inks, car care products, laundry detergents, gas and oil drilling in muds and packer } \\
\text { fluids preservation [11]. }\end{array}$ \\
\hline Nonanal & $\begin{array}{l}\text { Maintenance and repair of automobiles, Generic lubricants, lubricants for engines, brake fluids, oils, Personal } \\
\text { care products, including cosmetics, shampoos, perfumes, soaps [12]. }\end{array}$ \\
\hline Dodecane & $\begin{array}{l}\text { paraffin fraction of petroleum, breathing in gasoline fumes and automobile exhaust, inhaling some wood smoke, } \\
\text { or skin contact with petroleum products containing dodecane, refined oil products }[13,14]\end{array}$ \\
\hline Phthalic acid, isobutyl octyl ester & plastic manufacturing, additive in paints, lubricants, adhesives and insecticides [15] \\
\hline 1, 6 - octadien-3-ol,3,7,-dimethyl & perfumes, cosmetics and soaps, detergents and waxes [17] \\
\hline Estragole & pesticide products, food flavoring and in perfumes, de-greasers, spot removers [18] \\
\hline Benzene, azido & petroleum products, including motor fuels and solvents [19]. \\
\hline Butylated Hydroxytoluene & antioxidant, used to prevent oxidation in fluids (e.g. fuel, oil) [20]. \\
\hline 3 - isoprophyphenol & Crude oil, crude petroleum, refined oil products, fuel oils, drilling oils, production of metals [21] \\
\hline 1,2 - Bis (trimethylsilyl) benzene & Crude oil, crude petroleum, refined oil products, fuel oils, drilling oils, production of metals [21] \\
\hline 13-Hexyloxacyclotridec-10-en-2-one & Fragrance $[22]$ \\
\hline 9-Octadecenoic acid, methyl ester (E) & $\begin{array}{l}\text { Personal care products, including cosmetics, shampoos, perfumes, soaps, lotions, toothpastes, detergents, } \\
\text { emulsifiers, wetting agents, stabilizers, textiles treatment, plasticizers for duplicating inks, rubbers, waxes [16, 23] }\end{array}$ \\
\hline Napthalene, 2-methyl - & $\begin{array}{l}\text { Crude oil, crude petroleum, refined oil products, fuel oils, drilling oils, manufacturing of fertilizers, used for } \\
\text { preventing, destroying or mitigating pests, home products (cleaners, laundry products, air fresheners) [24] }\end{array}$ \\
\hline n-Nonycyclohexane & $\begin{array}{l}\text { It is present in all crude oils, paint and varnish remover, nylon intermediates, solvent for lacquers, resins and } \\
\text { synthetic rubber }[25,26]\end{array}$ \\
\hline $\begin{array}{l}\text { Tetrasiloxane decamethyl } \\
\text { Heneicosane }\end{array}$ & $\begin{array}{l}\text { Functional fluids (closed systems), Intermediates, Lubricants and lubricant additives, Personal Care Additive [23] } \\
\text { components in petroleum products [27] }\end{array}$ \\
\hline
\end{tabular}

\subsection{Health Risk Associated with Identified Pollutants}

The volatile organic compounds (VOCs) have also been reported to pose health risks, some of the compounds and reported health risks in Table 3:

Table 3. Possible health impacts of some VOCs found in the samples.

\begin{tabular}{ll}
\hline Compounds & Health impacts \\
\hline 1,2 benzisothiazol-3-amine & dermal exposure can cause skin sensitization and allergic contact dermatitis, also reported case of asthma when \\
Nonanal & inhaled [28-30] \\
Dodecane & Autism, Crohn's disease, Uremia, Ulcerative colitis, Crohn's disease, Celiac disease [12, 31 - 33] \\
Phthalic acid, isobutyl octyl ester & Cytotoxic effects, proinflammatory activities in human epidermal keratinocytes (HEK) [34] \\
2-Nitro-4-(trifluoromethyl) phenol & hormone disruption that affects development and fertility [35] \\
Methyl palmitate & Causes eye, skin and respiratory irritation [36] \\
\hline
\end{tabular}




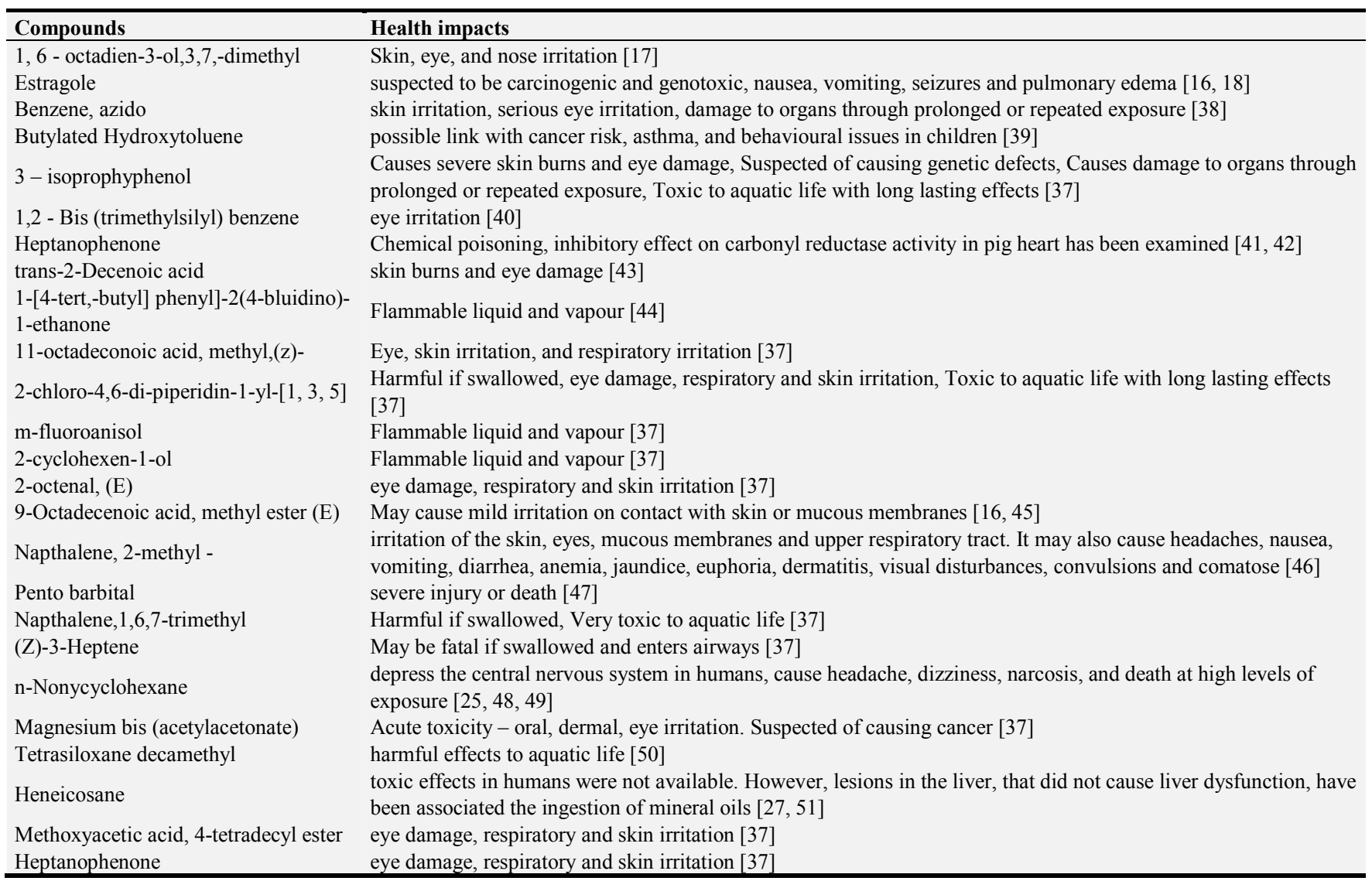

\section{Conclusion}

The sources of these contaminants may be geogenic and anthropogenic in origin, but some common sources are leaching of rusted USTs, emulsion paints, laundry detergents in car wash and lube bays within stations, lubricants, petroleum and engine fluids etc., and some reported health impacts are brain damage, cancer, tumours, neonatal defects, anaemia, central and peripheral nervous system breakdown, damage to the kidney, liver, bones, autism, Crohn's disease, uremia, ulcerative colitis, celiac disease, Skin, eye, and nose irritation, depress the central nervous system in humans, cause headache, dizziness, narcosis, and death at high levels of exposure.

Hence, the risk of contamination in groundwater resources at close proximities to filling stations is high and the impact of contaminants that can be released into the environment by the activities at these stations requires proper water treatment before use and consumption.

\section{References}

[1] Odipe, O., Lawal, A., Adio, Z., Karani, G., \& Sawyerr, H. (2018). GIS-Based Location Analyse of Retail Petrol Stations in Ilorin, Kwara State, Nigeria. International Journal of Scientific \& Engineering Research, 9 (12), 790-794.

[2] FGN. (2007). Legal Notice on Publication of the 2006 Census Report. Federal Government of Nigeria official Gazette, 4 (94), 1-8.
[3] Club, S. (2011). Leaking underground storage tanks: A threat to public health \& environment. San Francisco.

[4] Rockett, L., Gee, R., Aldous, E., Benson, V., Brandon, Y., Briere, B.,... \& Watts, C. (2014). Volatile organic compounds-Understanding the risks to drinking water. Toxicology Letters, (229), S127.

[5] Adelana, S. M. A; Olasehinde, P. I; Bale, R. B; Vrbka, P; Goni, I. B and Edet, A. E. (2008). An overview of the geology and hydrogeology of Nigeria. In: (Adelana SMA and MacDonald AM eds.). Applied Groundwater Studies in Africa. IAH Selected Papers on Hydrogeology, Volume 13: 171-197, CRC Press/Balkema, London.

[6] Obaje, N. G. (2009). Geology and mineral resources of Nigeria (Vol. 120). Springer.

[7] Olorunfemi, M. O., Fatoba, J. O., \& Ademilua, L. O. (2005). Integrated VLF-electromagnetic and electrical resistivity survey for groundwater in a crystalline basement complex terrain of Southwest Nigeria. Global Journal of Geological Sciences, 3 (1), 71-80.

[8] Oyegun, R. O. (1983). Water Resources in Kwara State. Matanmi and Sons printing and publishing Co. Ltd. Ilorin.

[9] Ajadi, B. S., Adaramola, M. A., Adeniyi, A., \& Abubakar, M. I. (2016). Effect of effluents discharge on public health in Ilorin Metropolis, Nigeria. Ethiopian Journal of Environmental Studies and Management, 9 (4), 389-404.

[10] Iroye, K. A. (2017). Correlating pattern of river discharge with degree of urbanization in sub-catchments of River Asa in Ilorin, Nigeria. Ethiopian Journal of Environmental Studies and Management, 10 (2), 251-261. 
[11] U.S. Environmental Protection Agency (US EPA) (2005) Reregistration eligibility decision (RED) for 1,2benzisothiazoline-3-one.

http://www.epa.gov/oppsrrd1/REDs/benzisothiazolin_red.pdf.

[12] PubChem, (2019a). National Center for Biotechnology Information. PubChem Database. Nonanal, CID $=31289$, https://pubchem.ncbi.nlm.nih.gov/compound/Nonanal (accessed on Nov. 11, 2019).

[13] Bingham, E., Cohrssen, B., \& Powell, C. H. (2001). Patty's toxicology. Volume 2: toxicological issues related to metals, neurotoxicology and radiation metals and metal compounds (No. Ed. 5). John Wiley and Sons.

[14] Verschueren, K. (2001). Handbook of environmental data on organic chemicals: Vol. 1 (No. Ed. 4). John Wiley and Sons, Inc.

[15] Alvarez-Rivera, G., Lores, M., Llompart, M., \& Garcia-Jares, C. (2013). Cosmetics and toiletries: chromatography.

[16] Lewis, R. J., Jr (1993) Hawley's Condensed Chemical Dictionary, 12th Ed., New York, Van Nos-trand Reinhold, p. 1217.

[17] PubChem, (2016). National Center for Biotechnology Information. PubChem Database. Linalool, CID $=6549$, https://pubchem.ncbi.nlm.nih.gov/compound/Linalool (accessed on Nov. 12, 2019).

[18] HMPC, (2005). Committee on Herbal Medicinal Products. Final Public Statement on the Use of Herbal Medicinal Products Containing Estragole. http://www.ema.europa.eu/docs/en_GB/document_library/Sci entific_guideline/2010/04/WC500089960.pdf.

[19] World Health Organization (WHO). (2015). Exposure to Benzene: A Major Public Health Concern. WHO Document Production Services.

[20] Yehye, Wageeh A.; Rahman, Noorsaadah Abdul; Ariffin, Azhar; Abd Hamid, Sharifah Bee; Alhadi, Abeer A.; Kadir, Farkaad A.; Yaeghoobi, Marzieh (2015). "Understanding the chemistry behind the antioxidant activities of butylated hydroxytoluene (BHT): A review". European Journal of Medicinal Chemistry. 101: 295-312. doi: 10.1016/j.ejmech.2015.06.026. PMID 26150290.

[21] Isaacs, K. K., Glen, W. G., Egeghy, P., Goldsmith, M. R., Smith, L., Vallero, D.,... \& Özkaynak, H. (2014). SHEDS-HT: an integrated probabilistic exposure model for prioritizing exposures to chemicals with near-field and dietary sources. Environmental science \& technology, 48 (21), 12750-12759.

[22] Kraft, P., \& Fráter, G. (2001). Enantioselectivity of the musk odor sensation. Chirality, 13 (8), 388-394.

[23] EPA, (2019b). Chemical Data Reporting under the Toxic Substances Control Act. Website: https://www.epa.gov/chemicals-under-tsca.

[24] EPA/ N. P. F. S. P. (2007). United States Environmental Protection Agency: Prevention, Pesticides And Toxic Substances., Washinton, pp.

[25] ACGIH (2008). Documentation of the Threshold Limit Values and Biological Exposure Indices. 7th ed. Cincinnati, OH: American Conference of Governmental Industrial Hygienists, 2008.
[26] HSDB. (2015). "National Library of Medicine Hazardous Substances Data Bank (HSDB).” 2015. http://toxnet.nlm.nih.gov/newtoxnet/hsdb.htm.

[27] HSDB, (2016). National Library of Medicine Hazardous Substances Data Bank. Available from, as of Nov 23, 2016: http://toxnet.nlm.nih.gov/newtoxnet/hsdb.htm.

[28] Kaur-Knudsen, D., Menné, T., \& Christina Carlsen, B. (2012). Systemic allergic dermatitis following airborne exposure to 1 , 2-benzisothiazolin-3-one. Contact dermatitis, 67 (5), 310-312.

[29] TOXNET, (2015). Toxicology Data Network, Fact Sheet, 1,2Benzisothiazoline-3-one National Library of Medicine. Website: https:/toxnet.nlm.nih.gov/cgibin/sis/search/a?dbs+hsdb:@term+@DOCNO+8271.

[30] Forschungsgemeinschaft, D. (2015). List of Substances. List of MAK and BAT Values 2015: Permanent Senate Commission for the Investigation of Health Hazards of Chemical Compounds in the Work Area, 19-162.

[31] James, S. J., Cutler, P., Melnyk, S., Jernigan, S., Janak, L., Gaylor, D. W., \& Neubrander, J. A. (2004). Metabolic biomarkers of increased oxidative stress and impaired methylation capacity in children with autism. The American journal of clinical nutrition, 80 (6), 1611-1617.

[32] Francavilla, R., Ercolini, D., Piccolo, M., Vannini, L., Siragusa, S., De Filippis, F.,... \& Serrazanetti, D. I. (2014). Salivary microbiota and metabolome associated with celiac disease. Appl. Environ. Microbiol., 80 (11), 3416-3425.

[33] Azario, I., Pievani, A., Del Priore, F., Antolini, L., Santi, L., Corsi, A.,... \& Bernardo, M. E. (2017). Neonatal umbilical cord blood transplantation halts skeletal disease progression in the murine model of MPS-I. Scientific reports, 7 (1), 9473.

[34] Yang, J. H., Lee, C. H., Monteiro-Riviere, N. A., Riviere, J. E., Tsang, C. L., \& Chou, C. C. (2006). Toxicity of jet fuel aliphatic and aromatic hydrocarbon mixtures on human epidermal keratinocytes: evaluation based on in vitro cytotoxicity and interleukin- 8 release. Archives of toxicology, 80 (8), 508-523.

[35] Koniecki, D., Wang, R., Moody, R. P., \& Zhu, J. (2011). Phthalates in cosmetic and personal care products: concentrations and possible dermal exposure. Environmental research, 111 (3), 329-336.

[36] European Chemicals Agency (ECHA) (2015a). European Chemicals Agency (ECHA) and data classification and on 2Nitro-4-(trifluoromethyl) phenol. Website: https://echa.europa.eu/information-on-chemicals/cl-inventorydatabase/-/discli/details/97711.

[37] UNECE (2017). About the GHS, Globally Harmonized System of Classification and Labelling of Chemicals (GHS). Available online: https://www.unece.org/trans/danger/publi/ghs/ghs_welcome_e .html.

[38] European Chemicals Agency (ECHA) (2015b). European Chemicals Agency (ECHA) and data classification and on azidobenzene. Website: https://echa.europa.eu/informationon-chemicals/cl-inventory-database/-/discli/details/134767.

[39] Wang, W., \& Kannan, K. (2019). Quantitative identification of and exposure to synthetic phenolic antioxidants, including butylated hydroxytoluene, in urine. Environment international, $128,24-29$. 
[40] European Chemicals Agency (ECHA) (2015c). European Chemicals Agency (ECHA) and data classification and on 1,2 - Bis (trimethylsilyl) benzene. Website: https://echa.europa.eu/information-on-chemicals/cl-inventorydatabase/-/discli/details/191884.

[41] Imamura, Y., Narumi, R., \& Shimada, H. (2007). Inhibition of carbonyl reductase activity in pig heart by alkyl phenyl ketones. Journal of enzyme inhibition and medicinal chemistry, $22(1), 105-109$.

[42] Pieprzyca, E., Skowronek, R., Korczyńska, M., Kulikowska, J., \& Chowaniec, M. (2018). A two fatal cases of poisoning involving new cathinone derivative PV8. Legal Medicine, 33, 42-47.

[43] European Chemicals Agency (ECHA) (2015d). European Chemicals Agency (ECHA) and data classification and on trans-2-Decenoic acid. Website: https://echa.europa.eu/information-on-chemicals/cl-inventorydatabase/-/discli/details/37727.

[44] European Chemicals Agency (ECHA) (2015e). European Chemicals Agency (ECHA) and data classification and on 1[4-tert,-butyl] phenyl]-2(4-bluidino)-1-ethanone. Website: https://echa.europa.eu/information-on-chemicals/cl-inventorydatabase/-/discli/details/46162.

[45] EPA, (2019). Chemical Data Reporting under the Toxic Substances Control Act. Website: https://www.epa.gov/chemicals-under-tsca.
[46] National Toxicology Program. Institute of Environmental Health Sciences, National Institutes of Health (NTP). 1992. National Toxicology Program Chemical Repository Database. Research Triangle Park, North Carolina: NTP via httn.canieochemicals.noaa.gov/chemical/20568.

[47] Guidebook (2004). A guidebook for first responders during the initial phase of a dangerous goods/hazardous materials transportation incident. US Department of Transportation, Transport Canada, and the Secretariat of Communications and Transportation Mexico. Washington, DC, USA.

[48] National Toxicology Program (2014). Testing Status of Agents at NTP. Available from, as of Jul 31, 2014: http://ntp.niehs.nih.gov/.

[49] USEPA/IRIS (2015) Integrated Risk Information System. Available from, as of Jul 31, 2014: http:/www.epa.gov/iris/.

[50] European Chemicals Agency (ECHA) (2015f). European Chemicals Agency (ECHA) and data classification and on Tetrasiloxane decamethyl. Website: https://echa.europa.eu/information-on-chemicals/cl-inventorydatabase/-/discli/details/46796.

[51] ATSDR (2016). Tox Profiles. Total Petroleum Hydrocarbons. Available from, as of Nov 23, 2016: http://www.atsdr.cdc.gov/toxprofiles/index.asp. 